\title{
ASSESSMENT OF CHEMICAL RESISTANCE OF BARRIER MATERIALS BASED ON PRACTICAL APPLICATION OF CONDUCTOMETRY
}

\author{
Pavel OTřÍSAL, Stanislav FLORUS
}

\author{
NBC Defence Institute of the University of Defence, Vyškov, Czech Republic \\ pavel.otrisal@unob.cz, stanislav.florus@unob.cz
}

\begin{abstract}
A paper deals with basic theoretical approaches for conductometry employment and its possibilities within testing chemical resistance of barrier materials. A classical conductometry is one from the oldest electro-analytical methods which deals with a measurement of conductivity of solution in water or even another solvent with high relative permittivity when comes to dissociation of an electrolyte on ions. Within employment of conductometric test for evaluation of chemical resistance of barrier materials used in anti-gas protection of the Czech Armed Forces Chemical Corps specialists based theoretical principles have been used. Their application, however, have reached a certain degree of rationalization such as the employment of special carbon electrodes, ensuring temperature compensation within performing long measurements and ensuring mixture of the electrolyte.
\end{abstract}

Keywords: Temperature compensation, KONDUKTOTEST, conductometry, conductometric cell, conductivity

\section{Introduction}

An effort about usage of classical analytical methods for their implementation into technical measurement systems able to provide relevant information related to chemical resistance of barrier materials used in the area of anti-gas protection is not new thing. This idea was discussed a number of workplaces, but the results were affected by a range of problems that their practical interpretation has significantly reduced or even made them impossible. At the time when works concerning development of electro-physical methods designated for enhancement of possibilities of testing barrier materials started at the Military Technical Institute of Protection in Brno, successes of Swiss professionals were known. Their results, however, were affected with a significant mistake. Subsequent improvements and long-term testing, which was conducted in cooperation across a wide range of research and educational institutions have produced results that allow you to easily reproduce the results, comment and draw relevant conclusions. For a very substantial authors consider that the results meet the requirements laid down in the standard EN ISO 6529 [1], which is regarded as a European standard and application foundation of American ASTM-F739 [2], which in essence enables a common understanding of virtually the entire technologically advanced world.

\section{General theoretical approaches to application of conductometry}

Conductometric methods belong to among widely used non-selective electro analytical techniques using specific chemical properties of the whole system 
between the electrodes, that is not only discrete phenomena at the interface between electrode and solution. Conductometric, in other words also conductivity measurements are applied where a given component can significantly and even a minimally influence the electrical conductivity of solutions or ultra pure water for which is assumed the highest possible value relative permittivity $\varepsilon$. Use of conductometry relates to the theory of electrical current in the solutions which is transmitted between the electrodes and migration of absolutely all present ions [35]. Electrical conductivity is an additive value which is directly proportional influenced by concentration, electric charge mobility, and respective ions, thus by kinds of ions of measured solution [6,7]. From the above it follows that conductometry is based on the ability of the electrolyte solution to conduct electric current and conductivity cell consists of two metal, usually platinum electrodes immersed in the solution to be analyzed. When the low frequency conductometry for measuring alternating current is used, thus there are no polarization platinum electrodes.

\subsection{Mathematical interpretation of} theoretical approaches to conductometry

Classics of analytical chemistry Kellö and Tkáč [8] to the electrical conductivity of electrolytes indicate that the conduction of electricity in electrolytes can be applied to all relationships arising from Ohm's law. From this law shows that the current $I$, thus the amount of charge transferred per one second, is proportional to the potential difference, respectively voltage $U$ at the ends of wires $(I=G . U)$ wherein $G$ is conductivity. In practice this means that a conductance $G$ in solutions depends on the content of ions, so that the greater is the content of ions in the matrix, the smaller the is resistance $\mathrm{R}$ and the greater is the conductivity G. By applying Ohm's law can be further inferred that the electrical resistance $R_{r}$ of solution is directly proportional to the length of the electrode $d$ and inversely proportional to the crosssection $E$ : [9]

$$
R_{r}=\rho_{v} \cdot \frac{d}{E},(1)
$$

where $\rho_{v}$ is the resistance of the conductor. The inverse (reciprocal) of resistance value $R_{r}$ of solution between electrodes to which the voltage $U$ is inserted is the conductivity $G=1 / R_{r}[10-13]$. The unit of conductivity is siemens $\left[\mathrm{S}=\Omega^{-1}\right]$. The conductivity of the electrolyte solution is determined by its specific conductivity (conductivity) $k_{v} \quad\left[\mathrm{~S} \cdot \mathrm{m}^{-1}\right]$. Like the conductance $G$ is the reciprocal of the resistance $R$ conductivity $k_{v}$ is inverse of resistivity $\rho_{v}$, thus $k_{v}=1 / \rho_{v}$. By modifying the equation (1) it gives: $[14,15]$

$$
\frac{1}{R_{r}}=\frac{E}{\rho_{v} \cdot d},
$$

thus

$$
G=k_{v} \cdot \frac{E}{d}(3)
$$

and then

$$
k_{v}=G \cdot \frac{1}{E}
$$

\subsection{Measurement of solution conductivity and possibilities of affection of results}

The constant electric tension $U_{l}$ (usually $0,2 \mathrm{~V}$ ) is put on carbon electrodes of the permeation conductometry cell sunk in redistilled water with resistance $R_{r}$ from the oscillator. Tension $\mathrm{U} 1$ is divided between the resistance of a conductivity bowl and a bleeder $R_{z}$. Its proportion $U_{2}$ on the resistance $R_{z}$ is directly proportional to conductivity of the solution $G$ because: [16]

$$
\frac{R_{z}}{R_{x}}=\frac{U_{2}}{U_{1}-U_{2}}(5)
$$


and subsequently

$$
G=\frac{U_{2}}{R_{z}\left(U_{1}-U_{2}\right)}
$$

Mathematical applications results from a construction of a basic electric scheme of the conductometer shown in the figure 1

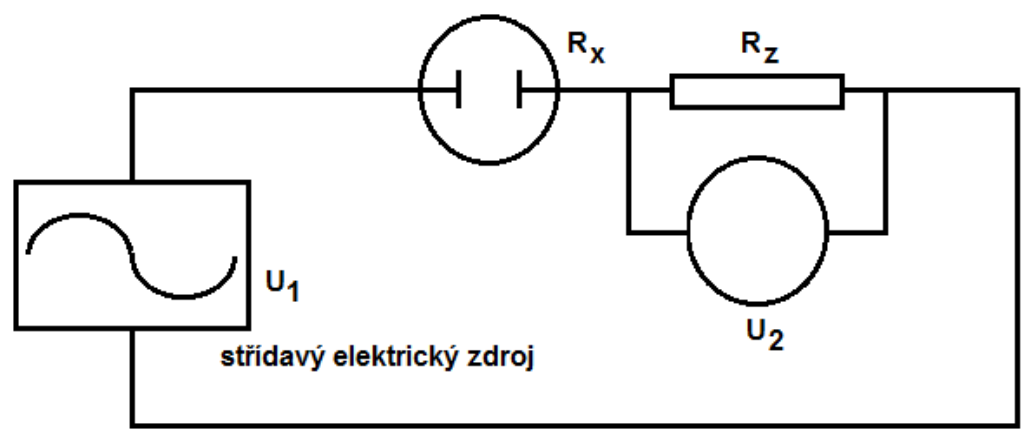

Figure 1: Basic electric scheme of the conductometer

The conductivity bowls are used in different variations of implementations concerning the purpose for which they are design in an analytical practice [17]. A conductometrical permeation cell which has been used for permeation measurements performance was made of Teflon. Special electrodes are inserted into its bottom part. The construction of electrodes in does usually not depend on their area and distance.

\section{Practical application of conductometry}

The area and distance of electrodes is constant within measurement of conductivity of the solution thanks to the construction of used conductometrical permeation cell. The proportion $1 / \mathrm{E}$ is thus possible to summarize into so called rheostatic constant of the bowl $k_{n}\left[\mathrm{~m}^{-1}\right.$ or $\left.\mathrm{cm}^{-1}\right]$. After that it is valid that:

$$
k_{v}=G \cdot k_{n} .(7)
$$

Taking into consideration that material used for construction of the Teflon conductometrical permeation cell of the KONDUKTOTEST device is not conductive it is possible to consider the value $k_{n}$ as the constant and in no way affecting achieved results. From the theory of conductivity results that specific conductivity $k_{v}$ is an additive quantity thus for specific conductivity of the solution $k_{s}$ is valid:

$$
k_{s}=\sum_{j=1}^{n} k_{v}
$$

The viscosity and relative permittivity $\varepsilon$ of the solvent have a great influence on conductivity. Since the viscosity is closely related to temperature of the solution the value of specific conductivity $k_{v}$ respectively $k_{s}$ also relate with temperature [18]. For aqueous solutions it is approximately valid that increasing a temperature $1{ }^{\circ} \mathrm{C}$ leads to increasing the conductivity of the solution of about $2 \%[19,20]$. Handbooks supplied with conductivity instruments [21] normally stipulate the need for record of temperature within conductometric measurements with that the ideal temperature for making measurements cins.der temperature limit from 20 to $25^{\circ} \mathrm{C}$.

To obtain the most accurate conductometric data it is necessary to fulfill and respect some important facts. Moore [22] for example states that in the relationship of changed conductivity $G$ of standardized solution $\mathrm{KCl}$ [within $20^{\circ} \mathrm{C}$ specific conductivity is $k_{v}\left(\mathrm{KCl}, \mathrm{c}=0.1 \mathrm{~mol}^{-1}{ }^{-1}\right)=$ $0.1278 \mathrm{~S} . \mathrm{m}^{-1}$ ] the very important characteristic of the measurement system is 
the rheostatic constant $k_{n}$ of the bowl. Another important factor of exact finding data concerning conductivity is total submersion and infestation of electrodes in order to have no gas on electrodes in the form of bubbles of the air or measured solution [23]. In practice this problem is solved in the way that the whole volume of redistilled water $(50 \mathrm{ml})$ with the value of the specific conductivity $3 \mathrm{~S}^{-1}$ has been dosed with the help of a one-piece pipette into the Teflon conductometrical permeation cell of the KONDUKTOTEST device on side opposite to the site where carbon electrodes are.

As mentioned above specific conductivity $k_{v}$ narrowly depends on temperature of the solution. For right measurement is thus necessary to work within constant and defined temperature, for example in a thermostatic chamber. Temperature of measured solution would not waver more than $\pm 0.25{ }^{\circ} \mathrm{C}$. Complying with these conditions, then the measurement error caused by the temperature difference is usually a maximum of $\pm 0.5 \%$. Despite the fact that the ideal temperature for performing conductometrical measurements states from 20 to $25{ }^{\circ} \mathrm{C}$ practical measurement have been performed within the temperature of $30{ }^{\circ} \mathrm{C}$. This temperature is consider as standard in the branch of individual protection from the reason that it expresses the relative relationship between the temperature of the body surface and the temperature of surrounding atmosphere. For these purposes, the measuring system is equipped with a sensor to measure the temperature. Ideally, it is appropriate to use such systems, which allow the automatic correction of the measured values. The software GRYF Magic XBC-8C in a variant of the KONDUKTOTEST device allows adjustment of temperature compensation and thereby to eliminate the effect of temperature on the results of permeation through test materials. Options of setting of temperature compensation are shown in figure 2 .

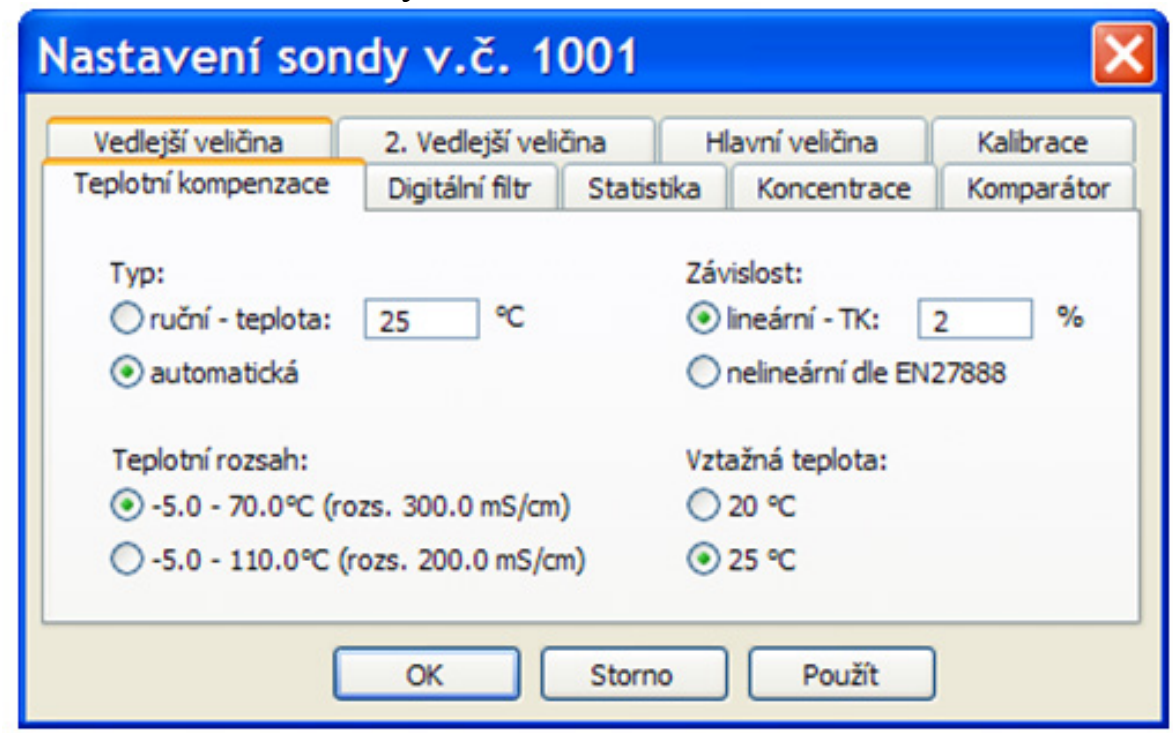

Figure 2: Setting of temperature compensation (in Czech) [24]

Setting introduced in figure 2 comes out from really performed measurements. The "Typ" lets you choose between automatic or manual temperature compensation. Temperature measured with in-built sensor into the carbon electrode is used when the automatic temperature compensation is chosen. Within manual temperature compensation it is possible to use temperature which is put into an editable window. Setting "Závislost" „lineární - TK“" is in accordance with EN 27888 [25] calculated with respecting linear dependence on temperature with the 
coefficient of temperature compensation which is put in percentages. Editing „vztažná teplota“ enables setting temperature to which are touched calculations of temperature compensation thus temperature within that will not be registered any effect of temperature compensation.

Due to the fact that measurements have been carried out by using principles of so called direct conductometry when the absolute value of electrical conductivity is measured, thermo stating is basically a principal condition. Another necessary condition for accurate measurements is to ensure minimal changes in the volume of electrolyte solution [26].

In a scope of electro-chemical and electro-metric methods is the same that the electrodes are detection system. In the case of the KONDUKTOTEST method two electrodes are used. Barek [27] states that: "Within conductometrical settings it is possible to meet with a general electrochemical problem - with the time change of the activity of electrodes in consequence of their direct contact with an analyzed environment, thus with the solution." Change in activity of electrodes may be manifested with a temporal change of an analytical signal even in the environment where the constant composition is. Usually decreases the provided signal. When using mercury dripping electrodes, thus electrodes having periodically refreshed surface is not necessary to this phenomenon, which is generally called the history of the electrodes to consider. A very serious problem, however, can happen in the case where electrodes from solid materials are used. Ways of solving the problems associated with the history of electrodes can be divided into several groups whose analysis will not be performed here.

\section{Employment of conductance to detection permeated toxic compounds through barrier materials}

In the introduction it was stated that efforts to monitoring the penetration of toxic compounds through tested barrier materials may be based on the principle of conductivity. It is therefore possible to state that the practical employment of KONDUKTOTEST methods assumes the application of the basic principle of electrometer methods, which are based on the absorption of gas (vapours) with absorption agent in this case in redistilled water. This principle is based on the electrochemical reaction, which involves a change in electrical properties of the solution. The KONDUKTOTEST equipment developed only for this purpose, enables the continual observation of increasing amount of the permeated test chemical in dependence on time. The minimal detection time there is 1 $\mathrm{s}$ and the maximal sensitivity of permeated toxic compound is $0,1 \mu \mathrm{g}$. When using the conductometric detection, it is possible to monitor only the permeation of those test substances which embody at least minimal measurable conductivity within absorption in water. Both equipment and method of KONDUKTOTEST is possible to use for the assessment of barrier materials designated for production of protective garments and their parts against the permeation of those toxic industrial materials and chemical warfare agents which embody acidobasic properties, thus they are dissolvable in water in the form of ionic solutions. With the help of KONDUKTOTEST method it is possible to determine the resistance of protective materials against the permeation of test chemicals in the scope of laboratory conditions based on the time of permeation, permeation mass, permeation rate and overall amount of permeated compound. Although this method allows detecting only the functional characteristics of the materials from which protective garments are produced, it is equally possible to perform testing of perspective or otherwise modified and improved materials. 


\subsection{Construction of the Teflon permeation conductometric cell}

Permeation cell of the

KONDUKTOTEST device uses a specially developed conductometric cell with in-built sensitive carbon detectors (conductometric sensors) for observing rate of permeation of toxic compound through barrier materials. These detectors consist of roller electrodes from glassy carbon. Setting of Teflon permeation conductometric cell of the KONDUKTOTEST device within determination of resistivity of non-porous polymeric membranes against permeation of volatile toxic compounds in static conditions is visible from figure 3 .

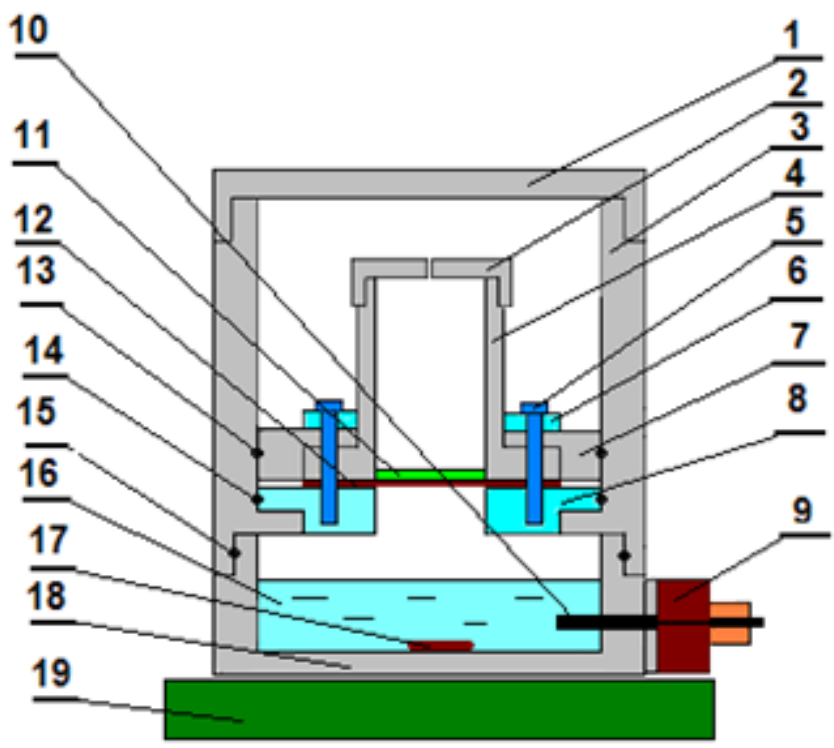

Figure 3: Setting of the Teflon permeation conductometric cell of the KONDUKTOTEST device

1-lid of the upper part of permeation cell, 2-inner lid of dosage part of sealing inset, 3-upper part of permeation cell, 4-dosage part of sealing inset, 5-tightening screws, 6-metal collar, 7-upper Teflon part of sealing inset, 8lower alumina or rustless part of the sealing inset, 9-conector, 10-two carbon electrodes, 11-test chemical, 12tested material, 13,14,15-sealing O-rings (Viton), 16-redestiled water, 17-smooth cylindrical stirrer with centric ringlet, 18-lower part of permeation cell, 19-magnetic stirrer

Redistilled water is dosed into the lower part of the permeation cell which is separable from the upper one. The smooth cylindrical stirrer with centric ringlet is put in redistilled water. This one, thanks to a magnetic stirrer on this the permeation cell is laid, with rotary movement ensures mixing of the electrolyte. This simple solution to eliminate problems with nonstandard courses of permeation curves that allow neither qualitative and quantitative evaluation of permeation measurement nor to describe permeation behavior. Two carbon electrodes whose surface was cleared of air bubbles are fully immersed in redistilled water respectively electrolyte. The upper part of the permeation cell is provided with a sample of test material with employment of six clamping bolts firmly connected after assembly. Deploying the upper part of the permeation cell on the bottom one is ready for dosing the liquid phase of the test chemical thus to the beginning of the measurement.

\section{Conclusions}

Theoretical and practical principles of conductometry have been verified and results discussed in the framework of elaborated studies focused on determination of the chemical resistance of permeable and non-permeable barrier materials of the Serbian Armed Forces in recent time. Results which have been compared with the results gained with the PIEZOTEST method were the same. Based on this fact it is possible to claim that for determination of the chemical resistance of tested barrier 
materials the employment of the KONDUKTOTEST method is better from the reason of avoiding damage of detector parts of the permeation cell. Nonetheless the user has to respect the only one principal condition - to use these chemicals which dissociate enough in water.

\section{References}

[1] ČSN EN ISO 6529 (83 2732): Protective clothing - Protection against chemicals Determination of resistance of protective clothing materials to permeation by liquids and gates (in Czech). Praha : Czech Normalization Institute, 2002. 36 p.

[2] ASTM F739: Standard Test Method for Resistance of Protective Clothing Materials to Permeation by Liquids or Gases Under Conditions of Continuous Contact. Philadelphia : American Society for Testing and Materials, 1999.

[3] PUNGOR, Ernő. A practical Guide to Instrumental Analysis. 1. vyd. Boca Raton : CRC Press LLC, 1995. 391 s. ISBN 0-8493-8681-0.

[4] KASTURE, V., A.; WADODKAR, G.,S.; MAHADIK, R., K.; MORE, N., H. Pharmaceutical Aanlysis: Volume I. 13. vyd. Nagar : Nirali Prakashan, 2007. I-2 s. ISBN 978-81-85790-07-7.

[5] BAGOTSKY, Sergeevich, Vladimir. Fundamentals of Electrochemistry. 2. vyd. New Jersey : John Wiley \& Sons, 2006. 722 s. ISBN 978-81-85790-07-7.

[6] DRBAL, Karel; KŘÍŽEK, Martin. Analytical chemicstry (in Czech). 1. vyd. České Budějovice : University of South Bohemia in České Budějovice, 1999. 185 p. ISBN 807040-352-7.

[7] RABILLOUD, Guy. High-Performance Polymers: Chemistry and Applications. 1. vyd. Pařiž : Technip, 2000. 579 s. ISBN 2-7108-0720-3.

[8] KELLÖ, Vojtech; TKÁČ, Alexander. Physical chemistry. 2. vyd. Bratislava : ALFAPublisher of technical and economical literature, 1972. $797 \mathrm{p}$.

[9] MASLIYAH, H., Jacob; BHATTACHARJEE, Surib. Electrokinetic and Colloid Transport Phenomena. 1. vyd. New Jersey : John Wiley \& Sons, 2006. 707 s. ISBN 978-0-471-78882-9.

[10] KLOUDA, Pavel. Modern analytical methods (in Czech). 2. vyd. Ostrava : Pavel Klouda Publisher, 2003. 132 p. ISBN 80-86369-07-2.

[11] Pages of University of Chemistry and Technology, Prague [online]. c2014. NOVÁK, Josef at al. Physical chemistry: Bachelor and Magister course (in Czech). [quated 201601-31]. Available from: < http://www.vscht.cz/fch/cz/pomucky/FCH4Mgr.pdf $>$

[12] VLÁČIL, František. Samples from chemici and instrumental analysis (in Czech). 2. vyd. Praha : SNTL-Technical Literature Publisher, 1978. 336 p.

[13] ZÝKA, Jaroslav at al. Analytical quidebook (in Czech). 2. vyd. Praha : SNTL-Technical Literature Publisher, 1973. 1040 p.

[14] STANĚK, Josef; DRBAL, Karel. Analytical chemistry (in Czech). 1. vyd. Praha : State Pedagogical Publisher, 1977. 183 p.

[15] NOVÁK, Josef. Physical chemistry: Bachelor Course. 1. vyd. Praha : University of Chemistry and Technology, Prague, 2005. 217 p. ISBN 80-7080-559-5.

[16] GARAJ, Ján; BUSTIN, Dušan; HLADKÝ, Zdeněk. Analytical chemistry (in Slovak). 1. vyd. Bratislava : Alfa, Technical and Economical Literature Publisher, 1987. 744 p.

[17] ŠANDERA, Karel. Conductometry (in Czech). 1. vyd. Praha : Czechoslovak Academy of Science Publisher, 1957. 341 p.

[18] CAMPANELLA, Humberto. FBAR, MEMS and NEMS Resonator Design and Applications. 1. vyd. Norwood : Artech House, 2010. 363 s. ISBN 978-1-60783-977-4. 
S. 168.

[19] SHINDÉ, L., Subhash; GOELA, S., Jitendra. High Thermal Conductivity Materials. 1. vyd. New York : Springer, 2006. 281 s. ISBN 0-387-22021-6.

[20] MACEŠKA, Radek. Measurement of conductivity of liquids (in Czech). [Bachelor thesis]. Brno : Brno University of Technology, The Faculty of Electrical Engineering and Communication. 2009.

[21] Pages Trinity College Dublin [online]. c2010. ANONYMOUS writer. Conductivity: Theory and Practise. [qoated 2014-03-28]. Available from: $<$ http://www.tcd.ie/Biochemistry/courses/js_conductivity.pdf $>$

[22] MOORE, J. Walter. Physical chemistry (in Czech) [translation by Čestmír Černý and Alexandr Schütz]. 4. vyd. Praha : SNTL-Technical Literature Publisher, 1972. 976 p.

[23] MIGUEL, M.; BURROWS, D., H. Progress in Colloid and Polymer Science: Volume 123. 1. vyd. Heidelberg : Springer, 2004. 722 s. ISBN 3-540-00553-6.

[24] FLORUS, Stanislav; OTŘÍSAL, Pavel; OBŠEL, Vladimír. Methodology of KONDUKTOTEST for quick determination of resistance of porous (filtration) and nonporous (isolative) barrier materials against the static permeation of sulfur mustard and other volatile toxic compounds with acidobasic properties dissolvable in water on ion dilution (in Czech). [Methodology for stationary laboratory]. Vyškov : NBC Defence Institute, $2013.75 \mathrm{p}$.

[25] ČSN EN 27888 (75 7344): Water quality. Determination of electrical conductivity (ISO 7888:1985) (in Czech). Praha : Czech Normalization Institute, 1996.

[26] DVOŘÁK, Jiří; KORYTA, Jiř́i; BOHÁČKOVÁ, Vlasta. Electrochemistry (in Czech). 2.vyd. Praha : Academia, 1975, 464 p.

[27] Pages of University of Chemistry and Technology, Prague [online]. c2016. BAREK, Jiř́. Possibilities of innovations in electro-analytical chemistry (in Czech). [quoted 2016-01-29]. Available from:

$<$ http://www.vscht.cz/anl/paci/PAC/prezentace/elektroanalytika.pdf> 